\title{
PENGEMBANGAN LKM MULTI REPRESENTASI BERBANTUAN GEOGEBRA UNTUK MENINGKATKAN KEMAMPUAN BERPIKIR KRITIS MAHASISWA
}

\author{
I Putu Wisna Ariawan \\ Jurusan Pendidikan Matematika, Fakultas MIPA \\ Universitas Pendidikan Ganesha \\ Singaraja, Indonesia \\ e-mail : putu_wisna_ariawan@yahoo.com
}

\begin{abstract}
Abstrak
Penelitian ini bertujuan untuk mengembangkan perangkat pembelajaran mata kuliah geometri bidang berupa lembar kerja multi representasi berbantuan Geogebra yang diharapkan dapat meningkatkan kemampuan berpikir kritis mahasiswa. Pengembangan perangkat pembelajaran dilakukan dengan menggunakan model 4 D Thiagarajan, Semmel and Semmel. Uji coba perangkat pembelajaran dilakukan dengan melibatkan mahasiswa kelas $B$ jurusan pendidikan Matematika FMIPA Undiksha yang mengikuti perkuliahan geometri bidang pada semester genap tahun akademik 2011/2012 sebanyak 34 orang mahasiswa. Hasil penelitian menunjukkan bahwa perangkat pembelajaran yang dikembangkan telah memenuhi syarat kualitas produk versi Nieveen yaitu valid, praktis dan efektif serta dapat meningkatkan kemampuan berpikir kritis mahasiswa.
\end{abstract}

Kata Kunci: Geogebra, multi representasi, kemampuan berpikir kritis

\begin{abstract}
The objective of this research is to develop the peripheral of plane geometry course such as multi representation students worksheet assisted by Geogebra which is expected to increase students' critical thinking skills. The development of this peripheral study were conducted by using the $4 \mathrm{D}$ model of Thiagarajan, Semmel and Semmel. The test of the peripheral was done by involving 34 students of class B of Mathematic Education Department, Faculty of Mathematics and Science, Ganesha University of Education who attending the plane geometry course in the second semester of academic year 2011/2012. The results showed that the peripheral that had been developed to meet the Nieveen's requirements of product quality such that valid, practical and effective and can increase students' critical thinking ability.
\end{abstract}

Key words: Geogebra, multi representation, critical thinking ability

\section{PENDAHULUAN}

Pembelajaran geometri bidang yang

dilaksanakan di jurusan pendidikan matematika FMIPA Undiksha sangat menuntut kemampuan berpikir tingkat tinggi bagi mahasiswa. Kemampuan 
berpikir yang dituntut tidak cukup hanya retention atau recall (retensi atau memanggil) maupun basic thinking (pemahaman konsep) tetapi setidaknya diperlukan kemampuan berpikir kritis (Santyasa, 2004).

Menurut Duval (1998), dalam aktivitas yang menyangkut geometri ada tiga jenis proses kognitiff yang harus disinergikan yakni proses visualisasi, proses konstruksi menggunakan alat dan proses bernalar. Ketiga proses ini haruslah dikoneksikan karena sinergi dari ketiga proses kognitif tersebut merupakan syarat perlu dalam mempelajari geometri. Sementara itu, Pederson (1993) menyatakan bahwa geometri merupakan suatu keterampilan yang melibatkan mata, tangan dan pikiran. Ada lebih banyak aspek visual dan dinamis pada geometri dibandingkan dengan bidang lainnya. Kedua pendapat di atas memberikan sinyal bahwa dalam pembelajaran geometri khususnya mata kuliah geometri bidang diperlukan suatu media yang mampu menyediakan fasilitas visual dan dinamis secara baik. Media yang tepat digunakan untuk menjawab permasalahan ini adalah media berbasis teknologi. Hal ini diperkuat oleh Hohenwarter, Hohenwarter, and Lavicza (2008), yang menyatakan bahwa sudah sepantasnya pada saat ini pembelajaran matematika khususnya geometri bidang haruslah dilakukan dengan cara mengintegrasikan teknologi ke dalamnya.

Pembelajaran geometri bidang dengan memanfaatkan media berbasis teknologi yang dapat memberi visualisasi dengan baik memang sangat dibutuhkan karena untuk dapat memahami suatu konsep atau teorema kadangkala perlu dilengkapi dengan ilustrasi berupa gambar. Gambar ini harus bisa diinterpretasikan dengan tepat. Menurut Van Blerk, Christiansen, and Anderson (2008), ada 3 faktor yang mempengaruhi kemampuan mahasiswa dalam menginterpretasikan suatu gambar geometri yakni: pengetahuan konseptual awal yang relevan dengan gambar, (2) keterampilan kognitif atau penalaran yang dimiliki untuk memvisualisasikan dan menilai gambar, dan (3) jenis gambar yang digunakan untuk merepresentasikan suatu konsep. Dengan demikian, sajian suatu gambar geometri ataupun bagian-bagian dari gambar sebenarnya merupakan representasi dari suatu konsep atau teorema.

Dari uraian di atas dapat disimpulkan bahwa berdasarkan karakteristik dari materi mata kuliah geometri bidang, setidaknya akan ada dua komponen yang bisa mempengaruhi hasil belajar mahasiswa. Pertama, tuntutan kemampuan berpikir kritis mahasiswa untuk dapat memahami materi, dan kedua, perlunya mengintegrasikan teknologi yang mampu menyediakan fasilitas visual dan dinamis secara baik yang menjadi jembatan bagi mahasiswa untuk memahami materi.

Berdasarkan hasil refleksi ini, dapat dikemukakan beberapa kelemahan di samping juga keunggulan terkait dengan pembelajaran geometri bidang.

Pertama, pada saat saat peneliti melaksanakan penelitian pada mahasiswa semester II jurusan Pendidikan Matematika tahun akademik 2010/2011, pada saat menyusun 
pembuktian, banyak mahasiswa yang hanya menggunakan alasan empiris dalam pembuktian. Misalnya jika pada $\triangle \mathrm{ABC}$ diketahui $\mathrm{D}$ adalah titik tengah dari $\overline{A B}$, mahasiswa menyatakan bahwa $\bar{C} \bar{D}$ adalah garis tinggi. Padahal fakta tersebut hanya berlaku jika $A C=$ BC. Kesalahan semacam ini memang sangat umum dilakukan oleh mahasiswa karena pada dasarnya untuk menyusun pembuktian adalah sesuatu yang sulit bagi mereka. Hal ini sesuai dengan pernyataan Stylianides (2011:2) yang menyatakan,

The concept of proof is central to meaningful learning of mathematics, but is hard for students to learn. A serious misconception dominant amongst students at all levels of schooling is that empirical arguments are proofs. An important question, then, is the following: What knowledge might enable teachers to help students overcome this misconception.

Kedua, pada saat peneliti melaksanakan penelitian pada mahasiswa semester II jurusan Pendidikan Matematika tahun akademik 2010/2011, peneliti telah memanfaatkan model reasoning and problem solving, buku ajar, buku petunjuk pemanfaatan open software Geogebra, serta LKM. Namun, peneliti menyadari perangkat pembelajaran yang digunakan khususnya LKM, belum dapat memberikan pengalaman proses kognitif secara optimal kepada mahasiswa sehingga kemampuan berpikir kritis mahasiswa belum dapat dikembangkan secara optimal. Oleh karenanya, perlu ada suatu "intervensi instruksional" yang harus dilakukan untuk mengatasi permasalahan yang ada melalui sejumlah aktivitas yang harus dirancang untuk mencapai sasaran pembelajaran. Stylianides (2011:3) menyatakan, "instructional intervention is meant a purposeful and cohesive collection of activities (and respective implementation strategies) for achieving particular learning outcomes".

Intervensi instruksional yang dapat dilakukan misalnya dengan merancang kegiatan terstruktur dan sistematis yang dapat memandu kegiatan mahasiswa dalam menggunakan LKM maupun sofware Geogebra. Untuk mencapai hal tersebut, LKM mesti dirancang secara sistematis yang didukung dengan pemanfaatan Geogebra secara optimal. Untuk dapat merancang suatu intervensi instruksional yang tepat, maka pengkajiannya perlu dilakukan dengan mengkaji esensi dari materi geometri bidang dan esensi dari berpikir kritis.

Pembelajaran student centered membutuhkan proses belajar dan pembelajaran yang kreatif, inovatif, dan kurikulum yang mendukung pembelajaran. Menurut Rajendran (2010), mengembangkan pebelajar yang mandiri (self-regulated learner) yang mampu memberdayakan kemampuan berpikir kritis, paradigma student centered lebih tepat digunakan. Kebanyakan penulis berpendapat bahwa berpikir kritis berkaitan dengan aktivitas "tingkat tinggi" seperti kemampuan dalam memecahakan masalah, menetapkan keputusan, berpikir reflektif, berpikir kreatif, dan mengambil kesimpulan secara logis (Nickerson, 1998). Sementara, Santyasa (2004) menyatakan bahwa berpikir kritis termasuk pada kategori berpikir tingkat tinggi dan reasoning.

Jurnal Pendidikan Indonesia | 361 
Berpikir kritis adalah proses yang melibatkan operasi mental seperti induksi, deduksi, klasifikasi, dan penalaran. Menurut Ennis (1993) berpikir kritis merupakan cara berpikir reflektif yang masuk akal atau berdasarkan nalar untuk menentukan apa yang akan dikerjakan dan diyakini. Berpikir menggunakan proses secara simbolik yang menyatakan objek-objek nyata, kejadian-kejadian dan penggunaan pernyataan simbolik untuk menemukan prinsip-prinsip mendasar suatu objek dan kejadian (Arends, 2004). Di dalam proses berpikir berlangsung kejadian menganalisis, mengkritik, dan mencapai kesimpulan berdasar pada inferensi atau pertimbangan yang seksama. Disampaikan oleh Diestler (1994) bahwa dengan berpikir kritis, orang menjadi memahami argumentasi berdasarkan perbedaan nilai, memahami adanya inferensi dan mampu menginterpretasi, mampu mengenali kesalahan, mampu menggunakan bahasa dalam berargumen, menyadari dan mengendalikan egosentris dan emosi, dan responsif terhadap pandangan yang berbeda

Tantangan terbesar yang dihadapi dalam pembelajaran geometri bidang bukan hanya melatih kemampuan mahasiswa untuk menghasilkan bukti ataupun melakukan proses pembuktian dengan benar, akan tetapi bagaimana agar mahasiswa bisa membuat koneksi makna antar komponen-komponen konstruksi formal yang ada pada bukti aksiomatis tersebut. Hal ini sesuai dengan pernyataan CadwalladerOlsker (2011:52) yang menyatakan,
"One challenge for educators is to help students to understand the value of formal, axiomatic proofs, while at the same time helping students to connect meaning to these formal constructions".

Terkait dengan multi representasi pada pembuktian dalam pembelajaran geometri Wong,Yin, Yang, and Cheng (2011) mengajukan tiga bentuk representasi yakni representasi masalah, representasi visual dan representasi bukti.

Jenis representasi yang pertama adalah representasi masalah atau representasi dari masalah itu sendiri yang umumnya dinyatakan dalam bentuk teks. Representasi masalah menentukan beberapa kondisi tertentu yang diketahui dan tujuan yang ingin dibuktikan. Mahasiswa perlu memahami simbol dan bahasa matematis, dan hubungan logis antara kondisi yang diberikan dan kondisi yang ingin dicapai.

Tipe kedua dari representasi adalah representasi visual. Representasi visual dapat disajikan secara statis ataupun dinamis. Sekelompok gambar statis bersama informasi yang relevan dari representasi masalah.

Korespondensi antara teks dan gambarnya dapat memberikan informasi tambahan bagi mahasiswa, yang dapat meningkatkan pemahaman mereka terhadap masalah geometri. Menurut Wong,Yin,Yang, \& Cheng (2011), suatu bukti yang disertai dengan sajian langkah pembuktian dari kondisi yang diberikan sampai pada suatu kesimpulan dengan urutan langkah deduktif dan gambar statis sederhana dapat memberikan bantuan kepada mahasiswa untuk membangun bukti. Mahasiswa secara visual dapat 
memeriksa apakah proposisi pada gambar tersebut valid. Dengan kata lain, gambar statis dapat menyediadan aturan pembatasan dalam interpretasi.

Permasalahan penelitian yang akan dijawab dalam penelitian ini dapat dirumuskan adalah sebagai berikut.

Apakah pemanfaatan LKM multi representasi berbantuan Geogebra pada perkuliahan Geometri Bidang dapat meningkatkan kemampuan berpikir kritis mahasiswa?

Menurut Duval (1998), dalam belajar geometri ada tiga jenis proses kognitif yang terlibat di dalamnya yakni: visualisasi, konstruksi dan penalaran. Sementara itu, Wong,Yin,Yang, \& Cheng (2011:45-46) menyatakan ada tiga bentuk representasi yang sangat bermanfaat untuk dilatihkan pada saat melatih kemampuan membuktikan yakni: representasi masalah, representasi visual dan representasi bukti.

atas, maka bentuk intervensi
instruksional yang dapat dirancang dalam pembelajaran geometri bidang adalah dengan merancang LKM yang dapat menyajikan representasi masalah, representasi visual dan representasi bukti serta dapat memanfaatkan software Geogebra untuk memberikan pengalaman kepada mahasiswa untuk melakukan proses kognitif visualisasi, konstruksi dan penalaran.

Tujuan umum dari penelitian ini adalah untuk mengembangkan perangkat pembelajaran berupa LKM multi representasi berbantuan Geogebra yang dapat diimplementasikan dalam pembelajaran geometri bidang yang diharapkan dapat meningkatkan kemampuan berpikir kritis mahasiswa yang nantinya juga diharapkan dapat bermuara pada peningkatan hasil belajar mahasiswa. Secara lebih eksplisit, tujuan dari penelitian ini dapat dirumuskan sebagai berikut.

a) Mengembangkan perangkat pembelajaran berupa LKM berbantuan Geogebra pada pembelajaran geometri bidang yang mampu menampilkan multi representasi dalam upaya meningkatkan kemampuan berpikir kritis mahasiswa.

b) Mensinergikan antara LKM multi representasi dengan perangkat pembelajaran sebelumnya (buku ajar dan buku petunjuk/pedoman pemanfaatan software Geogebra) sehingga dapat dijadikan sebagai sumber belajar berkualitas dalam pembelajaran geometri bidang.

c) Meningkatkan kualitas proses dan hasil perkuliahan geometri bidang yang mencakup: pemanfaatan berbagai sumber belajar yang berkualitas, kemampuan berpikir kritis dan hasil belajar mahasiswa

\section{METODE}

Dalam penelitian ini teknik pengumpulan data yang digunakan adalah: kuesioner angket, tes, observasi, dan wawancara. Sementara itu, instrumen penelitian yang digunakan dapat dirinci sebagai berikut.

\section{1) Lembar validasi oleh para ahli}

Para ahli adalah validator yang berkompeten untuk menilai validitas dari LKM multi representasi yang dikembangkan.

Lembar validasi ini digunakan oleh para ahli untuk memberikan validasi terutama terkait dengan: 
a. aspek format, aspek isi, aspek bahasa dan keluwesan untuk dapat dilakukan modifikasi.

b. Keterlaksanaannya dalam proses pembelajaran. Pada lembar validasi akan diisikan kolom rekomendasi yang akan diberikan oleh validator. Kolom rekomendasi itu terkait dengan keterlaksanaan perangkat dengan kriteria rekomendasi:

$\mathrm{A}=$ perangkat dapat digunakan tanpa revisi

$\mathrm{B}=$ perangkat dapat digunakan dengan sedikit revisi

$\mathrm{C}=$ perangkat dapat digunakan dengan banyak revisi

$\mathrm{D}=$ perangkat tidak dapat digunakan.

Dimodifikasi dari Yamasari (2010:3)

\section{2) Angket Tanggapan Mahasiswa}

Jenis angket yang diberikan kepada mahasiswa terdiri dari dua jenis. Angket pertama berupa angket untuk menjaring tanggapan mahasiswa terhadap LKM multi representasi yang digunakan. Pernyataan yang diajukan pada angket dirancang secara khusus untuk mengetahui keterlaksanaan LKM yang diimplementasikan jika dilihat dari sudut mahasiswa. Hasil angket ini akan digunakan untuk mengetahui keterlaksanaan/kepraktisan dari LKM yang dikembangkan.

Angket yang kedua berupa angket untuk menjaring respon mahasiswa terkait dengan perangkat LKM multi representasi yang dikembangkan. Pernyataan yang diajukan pada angket dirancang secara khusus untuk mengetahui respon umum mahasiswa perangkat LKM yang digunakan jika dikaitkan dengan upaya untuk mencapai hasil belajar mahasiswa secara umum. Hasil angket ini digunakan untuk mengetahui efektivitas dari LKM yang dikembangkan.

3) Tes

Tes yang digunakan untuk mengumpulkan data tentang kemampuan berpikir kritis mahasiswa berbentuk tes essay yang dikembangkan oleh peneliti dengan tetap mempertimbangkan aspek validitasnya berdasarkan masukan pakar dan teman sejawat. Sementara itu, untuk keperluan pengumpulan data hasil belajar mahasiswa akan digunakan tes hasil belajar berbentuk essay yang dikembangkan oleh peneliti dengan tetap mendiskusikannya dengan para pakar dan teman sejawat sehingga tes tersebut benar-benar representatif.

\section{4) Lembar Observasi}

Lembar observasi ini dibuat untuk mendapatkan informasi tentang kepraktisan perangkat terutama yang berkaitan dengan keterlaksanaan LKM. Data ini dikumpulkan oleh peneliti.

Lembar observasi ini dibuat untuk mendapatkan informasi tentang aktivitas belajar mahasiswa sebagai kriteria untuk menetapkan keefektifan perangkat LKM yang dikembangkan. Data ini dikumpulkan oleh peneliti.

\section{5) Catatan harian}

Catatan harian ini digunakan untuk mencatat hal-hal yang tidak mampu direkam melalui alat pengumpulan data yang telah disediakan. Hal-hal yang dicatat berkaitan dengan kejadian-kejadian yang terjadi selama pengimplementasian perangkat LKM. Data yang diperoleh dari catatan harian ini digunakan untuk menyempurnakan 
atau melengkapi data yang dikumpulkan dengan alat yang telah disediakan.

\section{HASIL DAN PEMBAHASAN}

Perangkat pembelajaran yang dikembangkan pada penelitian ini berupa LKM multi representasi berbantuan Geogebra. Hasil validasi yang diberikan oleh ketiga validator terkait dengan perangkat pembelajaran yang dikembangkan dapat disajikan pada tabel berikut.

Tabel 1 Hasil Validasi LKM yang Dikembangkan

\begin{tabular}{|c|l|c|}
\hline No & \multicolumn{1}{|c|}{ Aspek yang Dinilai } & Rerata Skor Validator \\
\hline 1. & Format & 3.167 \\
\hline 2. & Isi & 3.208 \\
\hline 3. & Bahasa & 3.167 \\
\hline 4. & Keluwesan & 4.000 \\
\hline & Rerata & 3.385 \\
\hline
\end{tabular}

Berdasarkan tabel di atas diperoleh rerata skor validator untuk perangkat LKM yang dikembangkan sebesar 3,385. Dari hasil penilaian ketiga validator, jika $\bar{P}$ adalah rata-rata skor ketiga validator ternyata $3 \leq \bar{P}_{i} \leq 4$. Berdasarkan kriteria validitas yang digunakan nilai ini menunjukkan bahwa ketiga validator menyatakan bahwa perangkat LKM yang dikembangkan berada pada kategori valid. Walaupun LKM yang dikembangkan sudah valid namun berdasarkan temuan ketiga validator, perlu dilakukan beberapa revisi pada LKM khususnya pada beberapa kesalahan pengetikan.
Berdasarkan hasil validasi di atas maka pada tahap develop telah dapat dihasilkan Draft II.

Practicality

Sebelum dilakukan uji coba, perangkat LKM yang dikembangkan akan divalidasi oleh validator untuk memberikan pertimbangan apakah perangkat LKM tersebut dapat diterapkan. Aspek practicality dari sisi mahasiswa dikaji melalui ujicoba terbatas di kelas melalui PTK. Hasil kajian practicality berdasarkan validasi ketiga validator dan penilaian mahasiswa dapat disajikan pada tabel berikut.

Tabel 2 Practicality Perangkat Pembelajaran LKM yang Dikembangkan

\begin{tabular}{|c|c|c|c|}
\hline \multirow{2}{*}{ No } & Penilai & Skor / Rerata & \multirow{2}{*}{ KP } \\
\hline \multirow{2}{*}{1} & Validator & \multirow{2}{*}{1} \\
\cline { 2 - 3 } & Ke-1 & 4 & \multirow{2}{*}{$100 \%$} \\
\cline { 2 - 3 } & Ke-2 & 4 & $75.42 \%$ \\
\hline 2 & Ke-3 & 3 & $87.71 \%$ \\
\hline \multicolumn{2}{|c|}{} \\
\cline { 2 - 3 }
\end{tabular}


Berdasarkan hasil penilaian seperti tertuang pada tabel di atas dapat dinyatakan bahwa perangkat LKM yang dikembangkan memenuhi kriteria practicality karena:

1) semua validator (100\%) memberikan pertimbangan bahwa perangkat LKM yang dikembangkan"dapat diterapkan tanpa revisi",

2) tanggapan mahasiswa terhadap perangkat LKM yang dikembangkan $(\bar{M})$ berada pada kategori "dapat diterapkan tanpa revisi”,

3) rerata penilaian tingkat keterlaksanaan perangkat LKM yang dikembangkan (KP) yang diberikan oleh validator dan tanggapan mahasiswa adalah $87,71 \%$ sehingga berada pada kriteria "dapat digunakan tanpa revisi”.

\section{Effectiveness}

Keefektifan perangkat LKM yang dikembangkan dilihat dari aktivitas mahasiswa selama mengikuti pembelajaran, kemampuan berpikir kritis mahasiswa, prestasi belajar mahasiswa, dan tanggapan mahasiswa terhadap perangkat LKM yang dikembangkan. Hasil pengamatan terhadap aktivitas mahasiswa selama berlangsungnya proses pembelajaran dapat disajikan pada tabel berikut.

Tabel 3 Skor Aktivitas Mahasiswa dalam Mengikuti Pembelajaran

\begin{tabular}{|c|c|c|c|}
\hline No & Komponen & Siklus I & Siklus II \\
\hline 1. & Total & 148.17 & 155.67 \\
\hline 2. & $\begin{array}{c}\text { Rerata Skor Aktivitas secara } \\
\text { Klasikal }\left(\overline{\mathrm{A}_{\mathrm{k}}}\right)\end{array}$ & 4.36 & 4.58 \\
\hline 3. & Persentase Aktivitas (PA) & $72.63 \%$ & $76.31 \%$ \\
\hline
\end{tabular}

Berdasarkan hasil yang tertuang pada tabel di atas dapat dinyatakan bahwa persentase aktivitas mahasiswa pada siklus I sebesar $72.63 \%$ berada pada kategori aktif. Walaupun nilai persentase aktivitas mahasiswa pada siklus II meningkat menjadi $76.31 \%$ namun tetap berada pada kategori aktif.

Aspek kedua dari keefektifan perangkat LKM yang dikembangkan adalah kemampuan berpikir kritis mahasiswa. Skor kemampuan berpikir kritis mahasiswa dihitung dengan menggunakan rubrik penskoran kemampuan berpikir kritis dengan mengadaptasi/memodifikasi The Holistic Critical Thinking Scoring Rubric yang telah dikembangkan oleh Facione and Facione (2009). Berdasarkan hasil uji coba terbatas sebanyak dua siklus diperoleh hasil kemampuan berpikir kritis seperti tertuang pada tabel berikut. 
Tabel 4 Perolehan Skor Kemampuan Berpikir Kritis Mahasiswa

\begin{tabular}{|l|c|c|c|}
\hline \multicolumn{1}{|c|}{ Komponen } & Siklus I & Siklus II & Hasil Akhir \\
\hline Rerata Perolehan Skor & 74.08 & 74.45 & 77.65 \\
\hline Tingkat Penguasaan & $74.08 \%$ & $74.45 \%$ & $77.65 \%$ \\
\hline
\end{tabular}

Tabel 5 Perolehan Tingkat Penguasaan Kemampuan Berpikir Kritis Mahasiswa

\begin{tabular}{|c|c|c|c|}
\hline \multirow{2}{*}{ Tingkat Penguasaan } & \multicolumn{3}{|c|}{$\begin{array}{c}\text { Banyaknya Mahasiswa yang Mencapai Tingkat } \\
\text { Penguasaan }\end{array}$} \\
\cline { 2 - 4 } & Siklus I & Siklus II & Hasil Akhir \\
\hline $85 \%-100 \%$ & 0 & 10 & 9 \\
\hline $70 \%-84 \%$ & 25 & 9 & 22 \\
\hline $55 \%-69 \%$ & 5 & 13 & 0 \\
\hline $40 \%-54 \%$ & 4 & 1 & 0 \\
\hline $0 \%-39 \%$ & 0 & 1 & \\
\hline
\end{tabular}

Berdasarkan perolehan skor kemampuan berpikir kritis mahasiswa, pada siklus I tingkat penguasaannya mencapai $74.08 \%$. Menurut pedoman konversi penilaian dengan PAP maka pencapaian ini berada pada nilai 3 atau B. Pada akhir siklus II terjadi kenaikan rerata tingkat penguasaan kemampuan berpikir kritis menjadi $74.45 \%$, namun tetap berada pada kategori nilai 3 atau B.

Aspek efektivitas yang terakhir adalah respon mahasiswa terkait dengan model dan perangkat yang dikembangkan. Item yang digunakan pada instrumen memiliki gradasi skor 1 (Sangat tidak setuju), 2 (Tidak setuju), 3 (Setuju) dan 4 (Sangat Setuju) untuk item yang arahnya positif dan sebaliknya jika arah itemnya negatif. Skor pada masing-masing item akan Berdasarkan hasil tabulasi angket diperoleh Total skor respon mahasiswa secara klasikal $\sum R_{k}=1469$, rata-rata skor respon mahasiswa
$\left(\overline{R_{k}}\right)=\frac{1469}{(14) \times(31)}=3,01$ dan Persentase Respon $\left(P_{R}\right)=\frac{\overline{R_{k}}}{4} \times 100 \%$ $=77.15 \%$.

Berdasarkan nilai $\mathrm{P}_{\mathrm{R}}$ sebesar $77.15 \%$ artinya mahasiswa memberikan tanggapan positif terhadap perangkat pembelajaran LKM yang digunakan.

Dari capaian-capaian di atas, terkait dengan efektifitas perangkat LKM yang dikembangkan diperoleh hasil sebagai berikut.

1) Aktivitas mahasiswa dalam mengikuti pembelajaran pada siklus I maupun siklus II berada pada kategori aktif.

2) Kemampuan berpikir kritis mahasiswa pada siklus I maupun siklus II berada pada rentang tingkat penguasaan $70 \%-84 \%$ dan terjadi kenaikan tingkat penguasaan dari siklus I ke siklus II.

3) Hasil belajar mahasiswa mencapai daya serap $77.65 \%$ dan ketuntasan belajar $100 \%$. 
4) Respon mahasiswa terhadap model dan perangkat yang digunakan berada pada kategori positif.

Dari keempat capaian di atas maka hasil penelitian menunjukkan bahwa perangkat LKM yang dikembangkan adalah efektif.

\section{PEMBAHASAN}

Seperti yang sudah dipaparkan pada bagian sebelumnya diperoleh hasil skor kemampuan berpikir kritis mahasiswa pada siklus I tingkat penguasaannya telah mencapai $74,08 \%$ dan berada pada kategori nilai 3 atau B. Beberapa faktor yang diidentifikasi dapat menunjang capaian tersebut adalah seperti berikut.

Adanya tuntutan untuk membuat representasi masalah pada LKM ternyata dapat "memaksa" dan sekaligus memberikan kesempatan kepada mahasiswa untuk berlatih menentukan kaitan atau hubungan logis antara kondisi-kondisi yang diberikan pada permasalahan dengan kondisi yang harus disasar. Hal ini akan mempermudah mahasiswa dalam menyusun strategi untuk memecahkan masalah yang dihadapi.

Adanya representasi visual yang dapat disajikan secara statis ataupun dinamis memungkinkan mahasiswa untuk melakukan penyelidikan lebih lanjut. Adanya gambar statis walaupun sederhana, ternyata dapat membantu mahasiswa dalam menyusun atau merumuskan langkah-langkah pembuktian.

Adanya gambar geometri dinamis yang dapat dimanipulasi oleh mahasiswa akan memungkinkan mahasiswa untuk mengamati berbagai perubahan yang terjadi untuk menyelidiki kebenaran proposisi yang dibuatnya dalam bukti formal. Gambar dinamis memungkinkan mahasiswa untuk menyalahkan proposisi atau pun meningkatkan tingkat kepercayaan terhadap proposisi yang diajukan melalui pengamatan pada gambar dinamis. Dengan adanya kegiatan memanipulasi gambar secara dinamis secara tidak langsung akan dapat mengasah kemampuan mahasiswa dalam menyusun pembuktian. Hal ini sesuai dengan pernyataan Aksoy, Bayazit, \& Soybaş (2010:191) yang menyatakan bahwa adanya sifat dinamis pada software Geogebra juga akan memungkinkan mahasiswa untuk mengembangkan kemampuan melakukan pembuktian maupun proses pembuktian.

Kelemahan yang masih dirasakan pada siklus I diantaranya adalah adanya beberapa mahasiswa masih kebingungan dalam membuat pohon bukti. Beberapa mahasiswa membuat pohon bukti secara terbalik sehingga mahasiswa akan kesulitan dalam membuat kesimpulan. Untuk mengatasi hal ini maka mahasiswa diingatkan tentang hakikat dari pohon itu sendiri yang pada bagian atas terdiri atas ranting-ranting. Ranting-ranting bisa dianalogikan dengan unsur-unsur yang diketahui sementara pada bagian bawah merupakan batang tunggal pohon yang nantinya akan menyasar pada hal-hal yang akan dibuktikan.

Seiring dengan berjalannya waktu dan semakin banyaknya pengalaman belajar yang diperoleh mahasiswa dalam memanfaatkan software geogebra pada siklus II, kemampuan berpikir kritis mahasiswa 
dapat ditingkatkan menjadi $74,45 \%$ dan berada pada kategori nilai 3 atau $B$.

Jika dibandingkan dengan capaian pada siklus I, ternyata terjadi kenaikan pencapaian rata-rata kemampuan berpikir kritis sebesar $0.37 \%$. Capaian pada siklus II sebenarnya cukup menggembirakan karena ada sebanyak 10 orang mahasiswa yang mampu mencapai tingkat kemampuan berpikir kritis pada kategori $85 \%$ - 100\%, sementara pada siklus I tidak ada mahasiswa yang mampu mencapai tingkat penguasaan ini.

\section{SIMPULAN DAN SARAN}

Dari hasil penelitian yang telah dilakukan dapat disimpulkan beberapa hal sebagai berikut.

1. Perangkat pembelajaran LKM multi representasi berbantuan Geogebra yang dikembangkan telah memenuhi tiga kriteria kualitas produk menurut Nieven yakni kriteria validity, practicality dan effectiveness.

2. Penerapan perangkat pembelajaran LKM multi representasi berbantuan Geogebra pada perkuliahan geometri bidang dapat meningkatkan kemampuan berpikir kritis mahasiswa.

3. Penerapan perangkat pembelajaran LKM multi representasi berbantuan Geogebra pada perkuliahan geometri bidang mampu menyebabkan tercapainya rerata hasil belajar mahasiswa secara klasikal sebesar 77,65 atau berada pada kategori nilai 3 atau $B$.

Saran yang dapat diajukan terkait hasil yang diperoleh pada penelitian ini adalah perlunya dilakukan uji coba terbatas kembali terkait dengan perangkat pembelajaran LKM multi representasi berbantuan Geogebra untuk mengetahui bagaimana idealnya perangkat pembelajaran ini dimanfaatkan dalam pembelajaran geometri bidang yang nantinya dapat mencapai tingkat kemampuan berpikir kritis mahasiswa yang paling optimal.

\section{DAFTAR PUSTAKA}

Abdulfatah, H. 2010. Improving Undergraduate Students'

Attitudes towards Geometric Proof through a Daily-Life Story using Dynamic Geometry Software. Paper Presented in The International I2GEO 2010 Conference, Hluboká nad VItavou, 2-3 July 2010. Tersedia pada

http://cermat.org/i2geo2010/dow nloads/files/ I2GEO2010bdelfatah.pdf. Diakses tanggal 1 Januari 2011.

Antohe, V. 2009. Limits of Educational Soft "GeoGebra" in a Criticall Constructive Review. Annals. Computer Science Series. 7th Tome 1st Fasc 2009, pp. 47-54

Aksoy, Y., Bayazit, İ. and Soybaş, D. 2010. The Effects of GeoGebra in Conjectures and Proofs, First North American GeoGebra Conference, 27 - 28 July 2010, pp. 190-195, Ithaca, New York, USA.

Arends, R. I. 2004. Learning To Teach $6^{\text {th }}$ Edition. New York: McGrawHill Co. Inc.

CadwalladerOlsker, T. 2011. What Do We Mean by Mathematical 
Proof? Journal of Humanistic Mathematics $\mathrm{Vol} 1$, No 1, January 2011, pp. 33-60.

Diestler, S. 1994. Becoming a Critical Thinker: A User Friendly Manual $4^{\text {th }} \quad$ Edition. New York: Macmillan.

Duval, R. 1998. Geometry from a cognitive point of view, in C. Mammana \& V., Villani (Eds.). Perspective on the Teaching of Geometry for the $21^{\text {st }}$ Centuy (pp. 37-51). Dordrecht, The Netherlands: Kluwer Academic Publishers.

Eggen, P. D. and Kauchak, D. P. 1996. Strategies for Teachers Teaching Content and Thingking Skills Third Edition. Boston: Allyn \& Bacon.

Ennis, R. H. 1993. Critical thinking assessment. Theory into Practice, 32, pp. 179-186.

Facione, $\mathrm{P}$ and Facione, N. 2009. The Holistic Critical Thinking Scoring Rubric. California: California Academic Press. Tersedia pada http://www. insightassessment.com/ 9HCTSR.html. Diakses tanggal 5 Maret 2011

Fadillah, S. 2008. Representasi dalam Pembelajaran Tersedia Matematika. http://fadillahatick.blogspot.com/2 008/06/reoresentasimatematik.html. Diakses tanggal 6 Februari 2012.

Godwin, S. and Sutherland, R. (2004) Whole class technology for learning mathematics: the case of functions and graphs, Education, Communication and Information, 4 (1), 131-152.

Hohenwarter, J., Hohenwarter, M., and Lavicza, Z. 2008. Introducing Dynamic Mathematics Software to Secondary School Teachers: The Case of GeoGebra. Journal. of Computers in Mathematics and Science Teaching Vol. 28, No. 2, pp.135-146.

Hohenwarter, M. and Lavicza, Z. 2008. The strength of The Community: How GeoGebra Can Inspire Technology Integration in Mathematics Teaching. MSOR Connections Vol 9 No 2 May July 2009, pp. 3 - 5.

Hohenwarter, J., Hohenwarter, M., and Lavicza, Z. 2008. Introducing Dynamic Mathematics Software to Secondary School Teachers: The Case of GeoGebra. Journal. of Computers in Mathematics and Science Teaching (2008) 28(2), 135-146.

Lu, Y.W. A. 2008. Linking Geometry and Algebra: A Multiple-Case Study of Upper-Secondary Mathematics Teachers' Conceptions and Practices of GeoGebra in England and Taiwan, Unpublished Master's thesis, Cambridge: University of Cambridge, UK

Manizade, A.G and Mason, M. 2011. Choosing Geogebra Applications Most Appropriate For Teacher's Current Geometry Classroom: Pedagogical Perspective. International Journal of 
Educational Studies in Mathematics, 76(1), 214-218.

Nickerson, R. S. 1988. On improving thinking through instruction. Review of Research in Education, pp. 15, 3-57.

Nieveen, N. 1999. Prototyping to Reach Product Quality. In Jan Van den Akker, R.M Branch, K. Gustafson, N. Nieveen, \& $\mathrm{Tj}$. Plom (eds). Design Approach and Education and Training. (pp. 125-135). Dordrecht, The Netherlands: Kluer Academic Publishers

Pederson, J. 1983. Why We Still Need to Teach Geometry." In Proceedings of the Fourth International Congress on Mathematical Education (Boston: Birkhauser Boston), pp. 158-159.

Rajendran, N. 2010. Teaching Thinking Skills at Institutions of Higher Learning: Lessons Learned. Pertanika Journal of Social Sciences. \& Humanities, Vol. 18, Special Issues, pp. 1 - 14.

Stylianides, A.J. 2011. Towards a Comprehensive Knowledge Package for Teaching Proof: A Focus on The Misconception that Empirical Arguments Are Proofs. Pythagoras, 32 (1), pp. 43-54.

Santyasa, I W. 2004. Model Problem Solving dan Reasoning Sebagai Alternatif Pembelajaran Inovatif. Makalah. Disajikan dalam Konvensi Nasional Pendidikan
Indonesia (Konaspi) V, 5-9 Oktober 2004, di Surabaya.

Trianto, 2007. Model Pembelajaran Terpadu dalam Teori dan Praktek. Jakarta: Prestasi Pustaka.

Wisna Ariawan, I P 2006. Pengembangan dan Implementasi Pembelajaran Berbantuan Paket Program Mathematica dengan Setting Generatif untuk Meningkatkan Kualitas Perkuliahan Matematika Dasar pada Mahasiswa Jurusan Pendidikan Kesejahteraan Keluarga. Laporan Penelitian. Singaraja: Jurusan Pendidikan Matematika FPMIPA IKIP Negeri Singaraja.

Wong, W.K., Yin, S.-K., Yang, H.H., and Cheng, Y.H. 2011. Using Computer-Assisted Multiple Representations in Learning Geometry Proofs. Educational Technology \& Society, 14 (3), 43-54

Yamasari, Y. 2010. Pengembangan Media Pembelajaran Matematika Berbasis ICT yang Berkualitas. Prosiding Seminar Nasional Pascasarjana X ITS 2010, 4 Agustus 2010. ISBN 979-5450270-1. pp. 1-8. Tersedia pada http://www.snps.its.ac.id/data/ma kalah/Pengembangan\%20Media \%20Pembelajaran\%20Matematika\%20Berb asis\%20ICT\%20yang\%20Berkua litas.pdf. Diakses tanggal 1 Maret 2011.

Jurnal Pendidikan Indonesia | 371 